\title{
A Different Heart in Children's Literature: The Juvenile Literature in Medical Education
}

\author{
Ana Mallet, ${ }^{1,2}{ }^{\circledR}$ Fátima Geovanini, ${ }^{1}{ }^{\circledR 0}$ Luciana Andrade, ${ }^{1}$ David Kestenberg ${ }^{1}{ }^{\circledR}$ \\ Universidade Estácio de Sá, ${ }^{\prime}$ Rio de Janeiro, RJ - Brazil \\ Universidade Federal do Rio de Janeiro, ${ }^{2}$ Rio de Janeiro, $R J$ - Brazil
}

\begin{abstract}
José Saramago, Nobel Prize in Literature, is the author of a statement that provokes adult readers: "What if children's stories become mandatory reading for adults? Would they really learn what they've been teaching for so long?". ${ }^{1}$ It is in this context that literary texts dedicated to children have been used at times in medical education and clinical practice to bring up often invisible subjectivities.
\end{abstract}

\section{Introduction}

The scope of children's literature has exceeded the recommended age groups, and it is now accepted that the same book can be appreciated by different ages, depending on readers' demands and needs of each reader.

Supported by the Narrative Medicine reports, ${ }^{2-4}$ the possibility of using the so-called children's literature has been investigated as a tool in the approach of topics related to medical practice. The heart, for example, has often been addressed in children's literature. It is almost always presented as an organ linked to tenderness, benevolence and care, often tending to a certain stereotype. In this article, we intend to present four children's books, selected by the way in which they present the heart. We believe they can be used by both undergraduate medical students and health professionals, as support for multidisciplinary teams.

The following books will be approached: Daddy's heart is outside the compass, ${ }^{5}$ Hearts to millions, ${ }^{6}$ The man's heart of popp ${ }^{7}$ and The heart and the bottle. ${ }^{8}$

\section{Keywords}

Juvenile Literature; Education Medical; Heart.
In Daddy's heart is outside the compass, the mother's heart that "beats quiet and constant" is a safe place for the boy trembling for fear of the storm. The father, carrying a laptop and a cell phone, complained of a burning feeling on the left side of his chest, and of pain going down to the left hand. The mother then calls an ambulance and an examination is made: "ten cables coming out from the device... six cables placed on the chest, around the heart, and four in the arms and legs" - an electrocardiogram ("This strip of paper with zigzag lines is called electrocardiogram"). The doctor gives the diagnosis: "Unfortunately, you have suffered a heart attack," and the treatment has already begun: "We need to inject it directly into the blood, so it can be quickly effective", explains the doctor. While the mother cries, Joaquim realizes that his father's heart is also beating fast. "I think he is sad" (the heart, but also the father), thought Joaquim. In the hospital, the mother explains to Joaquim that "Daddy's heart no longer jumps with joy to live. They are both sad." But even with the boy's effort, the father doesn't smile.

One week after hospital discharge, the father exercises on a stationary bike and starts a healthy diet composed of vegetables and fruits, despite his preference for juicy roast pork. During a walk with his dad, Joaquim, feeling him very sad and distant, approached him by asking childish questions: "Does the goldfinch have a heart too?", "Can birds suffer a heart attack too?" For the first time since the heart attack, the father smiles with the boy's innocence. The book ends when, after a walk in the rain, the father feels touched when his son snuggles up to him and says "I'm hearing your heart beats." A tear falls from his father's eye. He starts a conversation with Joaquim about the heartbeats, the joy and sorrow in life. Joaquim is the center of the book, and the only character with a proper name. His father and mother are presented to highlight the repercussions of the situation for the boy. Despite the

Mailing Address: Ana Mallet

Avenida Presidente Vargas, 642. Postal Code: 22230-010, Rio de Janeiro, RJ - Brazil.

E-mail: alr.mallet@gmail.com 
book's somewhat didactic approach, it can help students to realize the whole network of repercussions behind a patient who suffers a heart attack. In this case, an event in a young patient with a child. And this situation can bring consequences not only from the emotional point of view, but also from social and economic ones. This didactic approach becomes even more explicit when, at the end of the book, we find the information on how to prevent and how to treat a heart attack, and what is a defibrillator, for instance. Besides, there are moments of poetry in the daily process in which father and son (re) approach and how Joaquim "finds a way to his father's heart," which "returned to beat normally".

Hearts to millions presents the heart with more subtle and poetic metaphors and situations. From a duality between what a child feels about the heart and what his older brother thinks, we can discuss an (false?) opposition between art and science. At first, the older boy, under the influence of teachers and school, considers the heart only as a muscle "with auricles, ventricles and other complicated names", the size of a closed hand and a constant heartbeat, even if varying with emotions. The younger boy asks: "If my heart is so small, how do so many things fit in it?". The illustration of the book follows the text: on the one hand the small heart muscle inside a pot, ready to be studied in an anatomy class. On the other hand, hearts of varying sizes and colors in contact with nature and life. The younger boy has a richer vision - he notices the differences in heartbeats when he's quiet: "when mom caresses my hair, my heart gets serene and beats slower"; he also starts to question the size of the heart: "sometimes I even think my heart is elastic. When I'm happy it gets huge, when I'm sad it seems to shrink and gets so tiny the size of a point." Some of everyday metaphors are translated by a child's innocence to: “... I'm suspicious that my aunt has a heart that is a safe as he heard his mother on the phone telling his aunt that she had to open her heart. The boy thought "my aunt locked her heart in such a way that she can't open it now. Poor thing... this must cause her affliction." And he also hears that the girl who works at the bakery has a "butter heart" and that "anyone who has heard of butter hearts has certainly heard of stone hearts." And the young boy sadly notes: "I try to explain these things to my brother, that the heart is not only a muscle, but he does not understand... Does he not understand that a heart has so much to tell!... of one thing I'm sure: there are no two hearts alike!". And he decides that "... if his heart is a muscle, my heart, that beats like a drum, is a box where I keep the things I feel every day!" And even a child realizes that "things can be joyful and sad at the same time and hearts can mix everything and disorganize them like dressing drawers."

In the third book, The man's heart of popp, a pop-up book of incredible beauty, the boy José Francisco says that his father was a good man and a "carpenter, although he would like to be a fisherman, as he felt tightly held by the waves". But..."my father was born with a weak heart... the days passed and he did not improve, he was weaker and weaker." His father missed people but "people didn't greet him anymore, because he wouldn't get out of bed. The heartbeat cluttered like a moth closed in a jar looking for the air." But the father was good with his hands and thought of "building a poplar heart to replace his, that was faltering." The doctor called him crazy because this had never been tempted. But the father, "slowly, not to get tired, carved a wooden heart." The poplar's heart had "small roots coming out of it, resembling small veins and arteries". The doctor still found it a silly idea but "had no choice than to try the risky operation" because the father's heart stopped working for a moment. The doctor, in despair, had no other choice, and it was not a surprise, "the operation was a success!". "His life resumed, he returned to work in carpentry, and dream of the sea... that was when he met my mother and fell in love." But, with time, his mother realized his father was changing, roots started to grow from his feet and one morning, his father "left home to walk in the woods and never came back." This story was told by a boy who did not

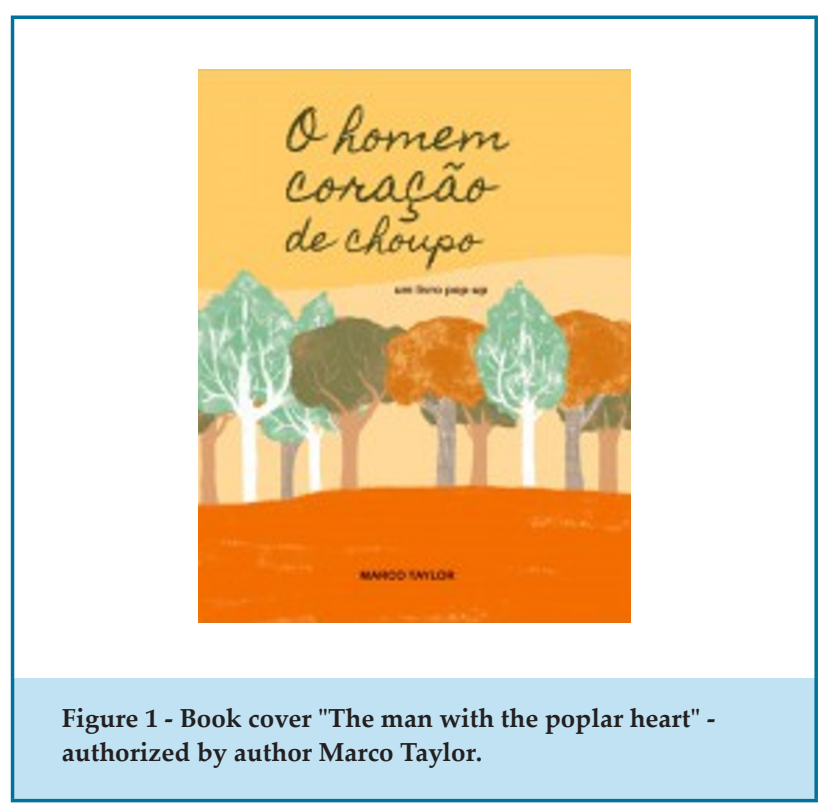


actually met his father but created his own story from reports of others and his imagination, and touchingly illustrates an approach of heart failure disease and heart transplantation through a child's eyes.

In The heart and the bottle, a girl full of life and energy keeps her heart in a supposedly safe place - a bottle - after a great loss, which is represented in the book by an empty chair. In the story, one day, the girl felt very insecure as she found the chair empty. The girl then thought the best thing to do was to put her heart in a safe place, "just for a while." She put her heart in a bottle, which she hung around her neck; "it seemed to fix things", thought the girl. But since then, the girl stopped paying attention at the sea, and even forgot the stars... the bottle started to become heavy, "but at least her heart was safe." Many years later, as she strolled on the beach, she meets a child, "curious about the world" as she herself used to be. The child asked her things she couldn't answer anymore, not without her heart. At that point she decides to rescue it from the bottle but did not know how to: she tried to saw the bottle, to throw it from a great height, she used a stick... but nothing worked. But the "little girl, still curious about the world thought that maybe there was a way." Her little hand managed to take the heart out of the bottle and "the chair was no longer empty". This is beautifully illustrated in the book. We have been used the image of the empty chair with students and health professionals in a technique called visual literacy: ${ }^{9}$ after the analysis of the image for a few minutes, participants are asked to write a text from a trigger phrase. In our case, the excerpt "the presence of absence" is used as the trigger in the dynamics.

\section{Conclusion}

In these four children's books, the heart has been associated with topics little addressed in children's literature: heart attack and infarction, the dichotomy emotional heart and biological heart, heart failure and heart transplantation, death and mourning. The use of this material in medical undergraduate programs can help promote a broader view of the impact of any of these events on someone's life, especially a child.

Considering that cardiovascular diseases are the leading cause of death in our country and that, unlike most of developed countries, they affect younger adults, their economic and social consequences may be more traumatic in a family's life. Maybe simple and poetic texts have the power to expand the perception of these conditions and their impact, by touching sensitive aspects of medical practice, and stimulating a critical posture in all the readers.

\section{Author contributions}

Conception and design of the research: Mallet A, Geovanini F, Andrade L, Kestenberg D. Obtaining financing: Mallet A. Writing of the manuscript: Mallet A, Geovanini F, Andrade L, Kestenberg D. Critical revision of the manuscript for intellectual content: Mallet A, Geovanini F, Andrade L, Kestenberg, D.

\section{Potential Conflict of Interest}

No potential conflict of interest relevant to this article was reported.

\section{Sources of Funding}

This study was funded by Bolsa Produtividade Universidade Estácio de Sá - RJ.

\section{Study Association}

This study is not associated with any thesis or dissertation work.

\section{References}

1. Saramago J. The largest flower in the world. São Paulo: Companhia das Letrinhas; 2001.

2. Charon R. Narrative medicine: a model for empathy, reflection, profession, and trust. JAMA.2001; 286(15):1897-902.

3. Charon R. Narrative medicine: honoring the stories of illness. New York: Oxford University Press; 2006.

4. Charon R, Dasgupta S, Hermann N, Irvine C, Marcus ER, Colón ER, Spencer D, Spiegel M. The principles and practice of narrative medicine. New York: Oxford University Press; 2017. 347 p.

5. Huainigg FJ; Ballhaus V. Daddy's heart is outside the compass. São Paulo: Editora Scipione; 2010.

6. Lopes J, Marques CC. Hearts to millions. Lisboa(Portugal):Editora Livros Horizonte; 2018.

7. Taylor M. The man's heart of popp.[Internet] [Cited in 2019 Jun 10] Available from: www.marcotaylorautor.com

8. Jeffers, O. The heart and the bottle. São Paulo: Editora Salamandra; 2012.

9. Capeloa Gil I. Literacia visual. Estudos sobre a inquietude das imagens Lisboa:Edições 70;2011. 